\title{
Cervical ectopic pregnancy: 10 year experience at tertiary care hospital and current literature review
}

\author{
R. C. Prameela, Sushma V. Dev*
}

Department of Obstetrics and Gynaecology, Mysore Medical College and Research Institute, Mysore, Karnataka 570001, India

Received: 05 January 2016

Accepted: 06 February 2016

\section{*Correspondence:}

Dr. Sushma V. Dev,

E-mail: docsushmavdev@gmail.com

Copyright: () the author(s), publisher and licensee Medip Academy. This is an open-access article distributed under the terms of the Creative Commons Attribution Non-Commercial License, which permits unrestricted non-commercial use, distribution, and reproduction in any medium, provided the original work is properly cited.

\begin{abstract}
Background: Objective of the study was to critically analyze the clinical experience and literature on cervical pregnancy.

Methods: This is a retrospective analysis of cervical ectopic pregnancies (CEP) diagnosed in our tertiary care institute from 2005 to 2015 and literature search.

Results: In this study period the total numbers of births in our institute were 1, 32, 752, ectopic pregnancies were 307 and three cases of cervical ectopic pregnancies were diagnosed. Incidence of CEP at our institute is $0.9 \%$ of all ectopic pregnancies and $0.002 \%$ or 1 in 44,250 of livebirths which matches the available literature. The first two cases developed torrential haemorrhage which ended in hysterectomy and the third case was managed conservatively with methotrexate (MTX) and mefiprestone.

Conclusions: The early detection of cervical pregnancy in asymptomatic or minimally symptomatic patients increases use of more conservative approaches which aim to preserve the uterus and the patient's reproductive potential. We suggest that systemic administration of low dose MTX is ideal for patients who are stable and if live embryo is detected, to reduce MTX failure rate concomitant feticide must be done, for which mefiprestone seems to be easy safe alternative to local chemotherapy.
\end{abstract}

Keywords: Cervical pregnancy, Ectopic pregnancy, Methotrexate, Mefiprestone, Expectant management

\section{INTRODUCTION}

Ectopic pregnancy constitutes approximately $2 \%$ of all pregnancies. It is one of the main causes of maternal mortality and morbidity in the first trimester. ${ }^{1}$ Tubal ectopic pregnancy is the most common type of ectopic pregnancy and is responsible for $95 \%$ of cases. Cervical ectopic pregnancies (CEP) are uncommon varient, on the other hand, make up $0.2 \%$ of all ectopic pregnancy cases. ${ }^{2}$ The reported incidence of CEP is 1 in 1000 95000 pregnancies. ${ }^{3}$ The etiology is unknown in most cases. Patients with this variant of ectopic gestations are at a high risk of potentially life-threatening haemorrhage. Before 1980, the diagnosis commonly was made when dilation and curettage for presumed incomplete abortion resulted in unexpected haemorrhage necessitating hysterectomy. Diagnosis and treatment of cervical ectopic pregnancy has changed dramatically in the last 2 decades. Transvaginal ultrasonography (USG) and Doppler study are the recommended diagnostic tools for CEPs. ${ }^{4}$ With the improved access to USG facilities and the rapid assay of serum human chorionic gonadotropin (HCG), the trend of modern clinical practice is rather destinated to conservative management consisting of medical and interventional measures hence preserving the fertility.

In this article we present our clinical experience with varied clinical presentations of CEP and management options. We have reviewed the literature on the probable 
etiology, diagnosis and available medical, conservative surgical management of CEPs.

\section{METHODS}

The retrospective study was conducted at Mysore medical college and research institute in the department of obstetrics and gynaecology. All the data were collected by reviewing the medical records on CEP cases managed at this tertiary care institute from July 2005 to June 2015. The study was approved by the institute review and ethical committee. In this study period three cases of CEP were detected. In all the cases clinical data were collected on age, parity, gestational age at diagnosis, HCG value, presence of fetal heart rate, clinical presentation, diagnosis method, management. Also data were collected on prior obstetric details as history of prior dilatation and curettage, history of prior caesarean section. Records were searched regarding total number of ectopic pregnancies managed, deliveries conducted in this period. On line literature search was done to collect all the relevant publications on CEP.

\section{RESULTS}

In this study period a total of 307 ectopic pregnancies were diagnosed at the institute. Total numbers of live births were 1, 32, 752 and three cases of CEPs were diagnosed in this study period. The incidence of CEP in our institute is $0.9 \%$ of ectopic pregnancies and $0.002 \%$ or 1 in 44,250 of all livebirths. The demographic characteristics of the patients are presented in Table 1 .

Table 1: Comparison of patient characteristics and management.

\begin{tabular}{|c|c|c|c|}
\hline & Case 1 & Case 2 & Case 3 \\
\hline Age (years) & 22 & 27 & 25 \\
\hline GA (weeks) & 7 & 9 & 8 \\
\hline $\begin{array}{l}\text { Gravidity } \\
\text { index }\end{array}$ & G1 & G3P1L1A1 & G2A1 \\
\hline FHB & No & No & Yes \\
\hline $\begin{array}{l}\beta \mathrm{HCG} \\
(\mathrm{miu} / \mathrm{ml})\end{array}$ & NA & NA & 85860 \\
\hline Prior D\&C & No & Yes & No \\
\hline Prior CS & No & Yes & No \\
\hline $\begin{array}{l}\text { Bleeding at } \\
\text { presentation }\end{array}$ & ++++ & ++++ & + \\
\hline $\begin{array}{l}\text { Initial } \\
\text { presentation }\end{array}$ & $\begin{array}{l}\text { Mimicking } \\
\text { incomplete } \\
\text { abortion }\end{array}$ & $\begin{array}{l}\text { Mimicking } \\
\text { incomplete } \\
\text { abortion }\end{array}$ & $\begin{array}{l}\text { Stable with } \\
\text { minimal } \\
\text { spotting } \\
\text { USG } \\
\text { confirmation } \\
\text { of CEP }\end{array}$ \\
\hline Management & $\begin{array}{l}\text { Curettage, } \\
\text { TAH }\end{array}$ & $\begin{array}{l}\text { Curettage, } \\
\text { TAH }\end{array}$ & $\begin{array}{l}\text { MTX+ } \\
\text { Mefiprestone } \\
\text { Curettage, } \\
\text { Balloon } \\
\text { tamponade }\end{array}$ \\
\hline
\end{tabular}

GA - gestational age, FHB- fetal heart beat, D\&C- dilation and curettage, $\mathrm{CS}$ - caesarean section, NA - not available, TAH total abdominal hysterectomy

In the first two cases patients presented with history of two months amenorrhoea and excessive vaginal bleeding which was thought as incomplete abortion. On attempting curettage torrential bleeding ensued which made us to suspect possibility of CEP. To control haemorrhage emergency laparotomy was done and ended as hysterectomy as final measure. Confirmation of CEP was made after histopathological correlation of uterus.

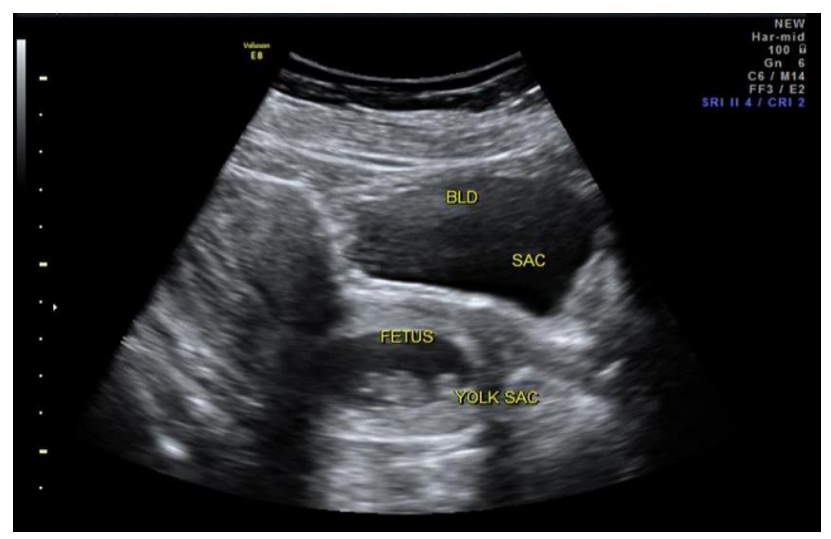

Figure 1: Transabdominal USG longitudinal view showing cervical pregnancy, empty uterine cavity.

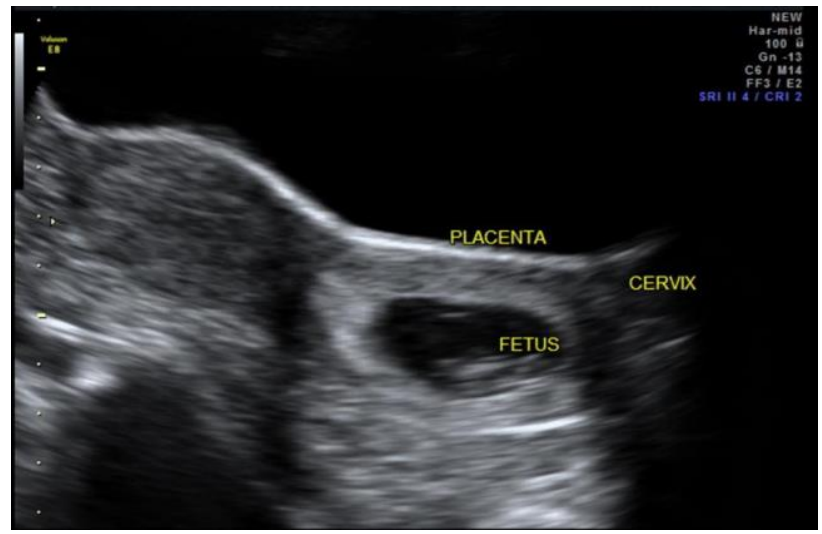

Figure 2: Transabdominal USG showing placental attachment in anterior cervical wall.

In the third case the patient presented in stable condition with 2 months amenorrhoea and minimal vaginal bleeding. On pelvic examination cervix was ballooned out, soft and bulky. Confirmation of CEP was made by pelvic ultrasonography (USG) which revealed live gestation of 7-8weeks with good fetal heart beat (FHB) also implantation of placenta in anterior wall of cervix. Uterine cavity was empty and internal os was closed (Figure 1, 2). Quantitative $\beta \mathrm{HCG}$ was $85860 \mathrm{miu} / \mathrm{ml}$ at presentation. In an attempt to preserve the fertility conservative management was decided. Her haemoglobin and biochemical parameters were normal. She received systemic intramuscular methotrexate $1 \mathrm{mg} / \mathrm{kg}$. Along with 
this oral mefiprestone $200 \mathrm{mg}$ was also given in view of high $\beta \mathrm{HCG}$ and live gestation. On day 4 repeat USG showed absent FHB, absence of colour Doppler uptake and $\beta \mathrm{HCG}$ had fallen to $56240 \mathrm{miu} / \mathrm{ml}$. On day 6 she complained of spontaneous expulsion of fleshy mass and massive bleeding PV. She was shifted to emergency operation theatre, bleeding was controlled after gentle curettage followed by balloon tamponade with foley's bulb. Her serial $\beta \mathrm{HCG}$ values showed downward trend and follow up USG showed normal cervical canal.

\section{DISCUSSION}

\section{Historical review and epidemiology of cervical pregnancy}

Cervical pregnancy is defined as the implantation of the conceptus below the level of the internal os. The first case of CEP was described in 1817. The reported incidence is highest in Japan lies between one in 978 live births and it is one in 56730 in the USA. ${ }^{2,5,6}$ In 1911 Rubin et al established the pathological diagnostic criteria for CEP:

a) Cervical glands must be opposite the placental attachment.

b) Placental attachment to the cervix must be situated below the entrance of the uterine vessels or below the peritoneal reflection of the anterior and posterior surfaces of the uterus.

c) Fetal elements must be absent from the corpus uteri.

Traditionally the diagnosis of cervical pregnancy was based solely on clinical findings and histology reports after hysterectomy or clinical diagnosis of cervical pregnancy was usually made when curettage for presumed incomplete spontaneous abortion resulted in uncontrollable haemorrhage and most women required emergent hysterectomy.,8 Until 1953, the reported mortality for women with cervical pregnancy was $45 \% .^{6,7,9}$ Two of our cases had similar presentation which required emergency hysterectomy. With the advent of newer diagnostic and therapeutic modalities hysterectomy and mortality rates have drastically comedown in the recent years.

\section{Etiology}

The etiology of CEP is still unclear. The proposed theories are:

a) Transport of the fertilized ovum might be too rapid for the possibly immature endometrium to accept it. ${ }^{10}$ Burg et $\mathrm{al}^{10}$ also considered the condition of fertilization in the cervix with subsequent implantation in the cervical canal, a theory that could be supported by Connor et al, who reported a pregnancy implanting at the stump of the cervix after supracervical amputation of the uterus. ${ }^{11}$ b) Damage to the cervix and endometrial lining during operative uterine procedures. ${ }^{7,12}$ The most common risk factor is dilatation and curettage (69\%), followed by previous caesarean delivery $(35 \%){ }^{13}$ Other risk factors include Asherman's syndrome, intrauterine devices, tumours and anomalies of reproductive tract. ${ }^{5,14}$ One patient in our study had curettage and prior caesarean history.

c) Invitro fertilization and embryo transfer (IVF- ET): Recently CEPs have been increasingly reported with assisted reproductive techniques including both intrauterine and intrafallopian tube embryo transfers. ${ }^{15-21}$

d) However, it has to be stated that the absolute risk remains rather small, because these factors are common but cervical pregnancy is rare.

\section{Clinical presentation and diagnosis}

The most common symptoms of cervical pregnancy are vaginal bleeding $(91 \%)$ and cramping pain (28\%). Early stage asymptomatic (6\%) cervical pregnancies may also be detected in routine ultrasonography. ${ }^{22,23}$ Clinical signs which suggest cervical pregnancy include a soft cervix that is enlarged in barrel shape, a partially open or closed external os, and profuse hemorrhage on manipulation of the cervix. A visible cervical lesion, often described as blue or purple and edematous in appearance, may be noted. $^{24,25}$ All our cases presented with similar symptoms as vaginal bleeding (100\%), pain (100\%) and third case had typical clinical signs of CEP. All these dictate the need of high index of clinical suspicion of CEP as women commonly present with similar complaints.

The diagnosis of early cervical pregnancy is now possible by transvaginal ultrasonography and serum $\beta \mathrm{HCG}$ determination. Early diagnosis of CEP is essential because this will decrease the occurence of acute complications and allow the preparation and implementation of a conservative approach. The first report of a cervical ectopic pregnancy diagnosed using ultrasound was in 1978 by Raskin. ${ }^{26,27}$ In 1993, TimorTritsch et al proposed more stringent criteria. ${ }^{28}$ the placenta and entire chorionic sac containing the live pregnancy must be below the internal os and the cervical canal must be dilated and barrel shaped. ${ }^{29}$ Diagnosis of cervical pregnancy is established by visualization of an intracervical ectopic gestational sac or trophoblastic mass. Ushakov et al suggested that visualization of an intact part of the cervical canal between the endometrium and gestational sac reflects an intracervical placentation. ${ }^{22}$ Table 2 presents USG criteria for diagnosis of CEP. Routine use of magnetic resonance imaging is not indicated for diagnosis of CEP.

Early cervical pregnancy may be mistaken for the cervical abortion. The larger or globular uterus, absence of FHB compared to the hourglass configuration in cervical pregnancy which is often accompanied with FHB are particularly helpful. ${ }^{22,29-33}$ Jurkovic et al 
described 'sliding sign' on transvaginal USG which occurs when the gestational sac of an abortus slides against the endocervical canal following gentle pressure by the sonographer and which will not be seen in an implanted cervical pregnancy may also assist in the differentiation. ${ }^{8}$ Benson and Doubilet disputed the usefulness of colour Doppler, stating the overlap of findings between miscarriage and cervical ectopic pregnancy was too great to add significant diagnostic information. ${ }^{34}$

\section{Table 2: USG diagnostic criteria for cervical pregnancy. ${ }^{22,28,29}$}

\section{Empty uterine cavity or thickened endometrium} Internal os closed

Gestational sac or placental tissue below the level of the internal os

Intact cervical canal between endometrium and sac

Negative 'sliding sign'

High peritrophoblastic vascularity on Doppler examination

Differentiation of a true cervical pregnancy from an isthmicocervical pregnancy is important and requires demonstration of a closed internal os and sac should be below the level uterine artery insertion in USG. ${ }^{8,22,31}$

\section{Management of cervical pregnancy}

With the recent advances in early diagnosis of CEP spectrum of conservative mode of treatment has become primary first line approach enabling preservation of fertility. Table 3 summarizes present study and studies and case reports published since 2000 onwards regarding management of CEP. ${ }^{13,20,21,23,27,29,30,35-52}$ Currently there are no specific recommendations for the best treatment of this entity. The modality of management in CEP depends on the clinical presentation and timely diagnosis, which can be conservative or radical. Treatment options can be categorized into 4 modes:

a) Medical therapy,

b) Minimally invasive surgical procedures,

c) Methods to reduce hemorrhage and

d) Hysterectomy.

In majority of reported cases more than one method were combined in the management.

\section{Medical therapy}

This should be the first step in conservative therapy when the diagnosis is made early in unruptured state and patient is hemodynamically stable. Methotrexate (MTX) is the most commonly used and well tested chemotherapeutic agent in medical management of ectopic pregnancy including CEP. ${ }^{8,27,30,35-52}$ Methotrexate treatment of cervical pregnancy was first performed by Farabow et al in $1983 .^{53}$ Since then, several cases have been reported in literature. Variable-dose, single-dose, low-dose, and high dose MTX regimens have been reported for cervical pregnancies (Table 3). Direct injection into the conceptus has also been investigated. ${ }^{13,27,35,40,41,51}$ Because the use of methotrexate in CEP is relatively new, a standardized protocol is not yet available, even for tubal pregnancy. ${ }^{54}$

Table 3: Summary of management of cervical pregnancies: a review of the literature.

\begin{tabular}{|c|c|c|c|c|c|c|c|c|c|c|c|}
\hline Reference & Year & $\mathbf{N}$ & HCG & FHR & $\begin{array}{l}\text { Systemic } \\
\text { MTX }\end{array}$ & $\begin{array}{l}\text { Local } \\
\text { therapy }\end{array}$ & curettage & $\begin{array}{l}\text { Other } \\
\text { treatment }\end{array}$ & $\begin{array}{l}\text { Successful } \\
\text { conservative } \\
\text { management }\end{array}$ & $\begin{array}{l}\text { Relevant } \\
\text { data }\end{array}$ & $\begin{array}{l}\text { Subsequent } \\
\text { pregnancy }\end{array}$ \\
\hline $\begin{array}{l}\text { Leeman } \\
\text { et } \mathrm{al}^{29}\end{array}$ & 2000 & 1 & 5800 & - & Yes & No & No & No & Yes & & \\
\hline $\begin{array}{l}\text { Pascual et } \\
\mathrm{al}^{35}\end{array}$ & 2001 & 1 & 83465 & + & No & $\begin{array}{l}\text { Yes } \\
\text { (MTX) }\end{array}$ & Yes & No & Yes & $\begin{array}{l}\text { IVF } \\
\text { Twin CEP }\end{array}$ & Yes \\
\hline Gun et $\mathrm{al}^{30}$ & 2002 & 1 & 23060 & + & Yes & No & No & UAE & Yes & & \\
\hline 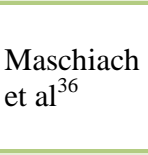 & 2002 & 8 & & + & Yes & - & yes & $\begin{array}{l}\text { 4 Shirhodkar } \\
\text { circlage }\end{array}$ & yes & $\begin{array}{l}7 \text { IVF } \\
1 \text { heterotopic } \\
\text { pregnancy }\end{array}$ & $\begin{array}{l}\text { Heterotopic } \\
\text { pregnancy } \\
\text { had live } \\
\text { birth }\end{array}$ \\
\hline 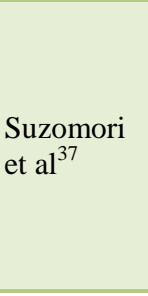 & 2003 & 1 & 32000 & & Yes & - & - & $\begin{array}{l}\text { Cervical } \\
\text { cerclage, } \\
\text { uterine artery } \\
\text { ligation, } \\
\text { unilateral } \\
\text { internal } \\
\text { iliac artery } \\
\text { ligation }\end{array}$ & Yes & & \\
\hline 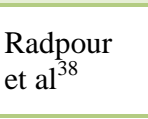 & 2004 & 2 & & + & Yes & - & - & $\begin{array}{l}\text { UAE, } \\
\text { Foley balloon } \\
\text { tamponade, }\end{array}$ & Yes & $\begin{array}{l}\text { Consecutive } \\
\text { CEP }\end{array}$ & Yes \\
\hline
\end{tabular}




\begin{tabular}{|c|c|c|c|c|c|c|c|c|c|c|c|}
\hline & & & & & & & & $\begin{array}{l}\text { Hysteroscopic } \\
\text { cautery of } \\
\text { cervical bed }\end{array}$ & & & \\
\hline $\begin{array}{l}\text { Cepni et al } \\
39\end{array}$ & 2004 & 1 & 35700 & + & Yes & - & - & - & Yes & & \\
\hline $\begin{array}{l}\text { Hassiakos } \\
\text { et } \mathrm{al}^{40}\end{array}$ & 2005 & 6 & & $-/+$ & - & MTX & Yes & - & Yes & $\begin{array}{l}\text { Curettage as } \\
\text { definitive } \\
\text { treatment }\end{array}$ & \\
\hline $\begin{array}{l}\text { Kirk et } \\
\mathrm{al}^{27}\end{array}$ & 2006 & 7 & & $-/+$ & Yes & $\begin{array}{l}\text { MTX, } \\
\text { KCL }\end{array}$ & - & - & Yes & & \\
\hline $\begin{array}{l}\text { Jeng et } \\
\mathrm{al}^{41}\end{array}$ & 2007 & 38 & & $-/+$ & $\begin{array}{l}\text { Yes (as } \\
\text { additional } \\
\text { dose in } \\
\text { some) }\end{array}$ & $\begin{array}{l}\text { MTX, } \\
\text { KCL }\end{array}$ & - & $\begin{array}{l}\text { Foley balloon } \\
\text { tamponade }\end{array}$ & Yes & $\begin{array}{l}\text { Local } \\
\text { MTX/KCL as } \\
\text { primary } \\
\text { therapy }\end{array}$ & Yes \\
\hline $\begin{array}{l}\text { Ferrata et } \\
\mathrm{al}^{13}\end{array}$ & 2007 & 1 & 10012 & + & Yes & $\begin{array}{l}\text { MTX+ } \\
\text { KCL }\end{array}$ & - & - & Yes & $\begin{array}{l}\text { Consecutive } \\
\text { CEP }\end{array}$ & \\
\hline 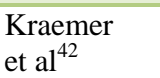 & 2008 & 1 & 231 & - & - & - & & $\begin{array}{l}\text { Excision of } \\
\text { CEP }\end{array}$ & Yes & & \\
\hline $\begin{array}{l}\text { Pathak et } \\
\mathrm{al}^{43}\end{array}$ & 2008 & 1 & 24000 & + & Yes & - & Yes & Mefiprestone & Yes & & \\
\hline $\begin{array}{l}\text { Verma et } \\
\mathrm{al}^{44}\end{array}$ & 2009 & 24 & & $-/+$ & Yes & KCL & & $\begin{array}{l}\text { UAE in } 1 \\
\text { case }\end{array}$ & yes & $\begin{array}{l}1 \text { IVF, I twin, } \\
3 \text { Heterotopic }\end{array}$ & \\
\hline $\begin{array}{l}\text { Song et } \\
\mathrm{al}^{45}\end{array}$ & 2009 & 50 & & & Yes & - & Yes & $\begin{array}{l}\text { Foley balloon } \\
\text { tamponade, }\end{array}$ & $\begin{array}{l}\text { Yes (in } 46 \\
\text { cases) }\end{array}$ & $\begin{array}{l}4 \text { cases had } \\
\text { hysterectomy }\end{array}$ & \\
\hline $\begin{array}{l}\text { Majumdar } \\
{\text { et } \mathrm{al}^{21}}\end{array}$ & 2009 & 1 & & + & - & KCL & - & - & Yes & $\begin{array}{l}\text { IVF, } \\
\text { Heterotopic } \\
\text { pregnancy }\end{array}$ & \\
\hline $\begin{array}{l}\text { Moon et } \\
\mathrm{al}^{46}\end{array}$ & 2010 & 1 & & & Yes & MTX & Yes & & Yes & & \\
\hline $\begin{array}{l}\text { Mohebbi } \\
\text { et al }{ }^{47}\end{array}$ & 2011 & 1 & 3490 & + & - & - & Yes & & Yes & & \\
\hline $\begin{array}{l}\text { Shreshta } \\
\text { et al }{ }^{48}\end{array}$ & 2011 & 11 & 20369 & + & Yes & & & Mefiprestone & $\begin{array}{l}\text { Yes (in } 9 \\
\text { cases) }\end{array}$ & $\begin{array}{l}\text { Hysterectomy } \\
\text { (in } 2 \text { cases) }\end{array}$ & \\
\hline $\begin{array}{l}\text { Delrieu et } \\
\mathrm{al}^{20}\end{array}$ & 2013 & 1 & & + & - & - & - & $\begin{array}{l}\text { Amniotic } \\
\text { aspiration }\end{array}$ & Yes & $\begin{array}{l}\text { IVF, } \\
\text { Heterotopic }\end{array}$ & Yes \\
\hline $\begin{array}{l}\text { Masuyama } \\
\text { et } \mathrm{al}^{49}\end{array}$ & 2013 & 15 & & +1 & Yes & - & - & UAE & Yes & & Yes \\
\hline $\begin{array}{l}\text { Pandey et } \\
\mathrm{al}^{50}\end{array}$ & 2013 & 1 & & & - & - & - & $\begin{array}{l}\text { Foley's } \\
\text { balloon } \\
\text { tamponade }\end{array}$ & No & Hysterectomy & \\
\hline $\begin{array}{l}\text { Genc et } \\
\mathrm{al}^{23}\end{array}$ & 2014 & 1 & 4452 & & Yes & - & Yes & & Yes & & \\
\hline $\begin{array}{l}\text { Sijanovic } \\
\mathrm{et} \mathrm{al}^{51}\end{array}$ & 2014 & 1 & 16553 & & - & MTX & - & $\begin{array}{l}\text { Foleys } \\
\text { balloon } \\
\text { tamponade, } \\
\text { hysteroscopic } \\
\text { resection }\end{array}$ & Yes & & \\
\hline $\begin{array}{l}\text { Tomov et } \\
\text { al }{ }^{52}\end{array}$ & 2015 & 1 & & & - & - & - & $\begin{array}{l}\text { Balloon } \\
\text { tamponade }\end{array}$ & No & Hysterectomy & \\
\hline $\begin{array}{l}\text { Present } \\
\text { study }\end{array}$ & 2015 & $\begin{array}{l}2 \\
1\end{array}$ & - & $\begin{array}{l}- \\
+\end{array}$ & Yes & $\begin{array}{l}- \\
-\end{array}$ & $\begin{array}{l}\text { Yes } \\
\text { Yes }\end{array}$ & $\begin{array}{l}\text { Mefiprestone, } \\
\text { Balloon } \\
\text { tamponade }\end{array}$ & $\begin{array}{l}\text { No } \\
\text { Yes }\end{array}$ & Hysterectomy & \\
\hline
\end{tabular}

(MTX - methotrexate, FHR- fetal heart rate, UAE- uterine artery embolization, N- number, HCG - human chorionic gonadotropin)

The success rate of exclusive administration of MTX has been reported to be as high as $81.3 \%$, while the percentage is increased to $90 \%$ when MTX is combined with additional conservative methods. ${ }^{55}$

According to Hung et al, failure of single MTX chemotherapy is likely if the gestational age is $\geq 9$ weeks, fetal viability is documented, serum HCG titer is $\geq 10,000$ milli-International Units/mL, or fetal CRL is greater than $10 \mathrm{~mm} .{ }^{56}$ Hung et al also reported that concomitant feticide would enhance the therapeutic effect of MTX and administration of high dose MTX was not more effective than low dose MTX. ${ }^{56}$ 
Ben Hamouda et al and Api et al have reported that exclusively single-dose intramuscular administration of MTX may be effective in treating cervical pregnancy without additional need for curettage. ${ }^{57,58}$

Feticide by local therapy consists of sonographically guided injection of medications, either intra-amniotic or intra-fetal. The most commonly reported medications are MTX and $\mathrm{KCl}^{13,21,27,35,41,44,46,51}$ Administration of intraamniotic prostaglandins F2 $\alpha$ have also been described by Spitzer et al and Vega et al. ${ }^{59,60}$

Mefiprestone administered along with MTX to induce feticide has been reported by Pathak et al and Shreshta et al. $^{43,48}$ In the presence of progesterone, mifepristone acts as a competitive receptor antagonist at the progesterone receptor. Mifepristone induces decidual breakdown indirectly, leading to trophoblast detachment and resulting in decreased syncytiotrophoblast production of $\mathrm{HCG}$, which in turn causes decreased production of progesterone by the corpus luteum. The combination of these two drugs will prevent the development of embryos and speed up embryonic death, which will definitely shorten the treatment time. The advantages of combining mefiprestone are easy oral route of administration, reduction in the dose of MTX and reduced MTX failure rate.

In our third case also same benefits were obtained by using mefiprestone. Hence, we could employ single low dose MTX even in the presence of high HCG titre. Administration of mefiprestone was easier compared to technical difficulties and risk of bleeding which may follow local KCL/MTX injection.

\section{Minimally invasive surgical procedures}

These procedures aim at removal of trophoblastic tissue and often follow the medical therapy as second line of treatment of CEP. These include curettage, aspiration, hysteroscopic endocervical resection, cervical amputation. ${ }^{12}$ This approach can cause haemorrhage requiring additional methods to reduce blood loss.

\section{Procedures to reduce haemorrhage}

Procedures to reduce blood supply to CEP can be used as third step approach of management if active bleeding is encountered during excision of cervical pregnancy when MTX proves unsuccessful. This can also be clubbed as secondary approach in preparation for surgical therapy like curettage or in combination with chemotherapy. The methods include intracervical ballon tamponade, cervical cerclage (shirhodkars), vaginal ligation of cervical arteries, uterine artery ligation, internal ileac artery ligation and angiographic embolozation of uterine or internal ileac arteries. ${ }^{36-38,41,45,51}$ Selective uterine arterial embolization (UAE) has become accepted as a highly effective technique for controlling acute or chronic genital bleeding. UAE is optimally employed prior to internal iliac artery ligation or hysterectomy and has various therapeutic advantages, such as avoidance of surgical risks and preservation of fertility. ${ }^{24,30,49}$ Although relatively safe UAE complications like uterine infarction, bladder necrosis have been documented. Hwang et al ${ }^{61}$ and Hsieh et al ${ }^{62}$ recommended vasopressin injection for cervical hemorrhage after local MTX. In our third case foley's balloon tamponade was employed to reduce bleeding.

\section{Hysterectomy}

If bleeding cannot be controlled by conservative measures, hysterectomy which is a radical approach should be performed as lifesaving measure. Primary hysterectomy may still prove to be appropriate in settings of intractable haemorrhage, second or third-trimester diagnosis of cervical pregnancy and possibly to avoid emergency surgery in a woman who does not desire fertility. ${ }^{23,50,52}$ The first two of our cases developed torrential bleeding which forced us to resort to hysterectomy as lifesaving measure.

\section{Subsequent fertility after CEP}

The fundamental principle of adopting the tedious conservative approach in CEP management is the immense concern in preserving the future childbearing potential. MTX, a cytotoxic drug, has been thought to have a potential mutagenic activity on human gamete and also teratogenic effect on the conceptus. Actually, total doses of MTX used during the entire treatment course of cervical pregnancy were not high when compared with those used for treating gestational trophoblastic tumours. $^{63}$ According to this observation, patients experiencing MTX administration are not likely to be at increased risk of fetal anomalies or spontaneous abortion in later conceptions. Also, it appears that when a sufficient portion of the cervix is preserved, cervical function is more likely to recover. According to studies by Kung et al and Jeng et al a prior cervical pregnancy with MTX treatment does not impair subsequent reproductive function and that the risk of infertility after MTX therapy does not generally increase. ${ }^{41,63}$ Still, these patients may be adviced contraception for 6 months to minimize potential teratogenic risks. Early USG is indicated in subsequent pregnancy to rule out recurrence of ectopic pregnancy. Pregnancy should be watched for possible complications like cervical incompitance or preterm labour.

Several reports of successful continuation of intrauterine pregnancy after local interventions to terminate CEP in cases of heterotopic pregnancies are available. ${ }^{20,21}$ It is prudent to watch for heterotopic pregnancies in conceptions following IVF and ET. 


\section{CONCLUSIONS}

Cervical pregnancy is an uncommon clinical entiety. Owing to the rarity of CEP, it is impossible to test various treatment methods by formal randomized trials. It is prudent to rely on case reports and small case series for practice guidelines. Presently, with the advent of endovaginal USG for early diagnosis and with utilization of spectrum of safe conservative approaches for treatment of CEP have reduced the associated morbidity and allow for preservation of future fertility. We suggest that systemic administration of low dose MTX is ideal for patients who are stable and if live embryo is detected, to reduce MTX failure rate concomitant feticide must be done, for which mefiprestone seems to be easy safe alternative to local chemotherapy.

\section{Funding: No funding sources}

Conflict of interest: None declared

Ethical approval: The study was approved by the Institutional Ethics Committee

\section{REFERENCES}

1. Agdi M, Tulandi T. Surgical treatment of ectopic pregnancy. Best Pract Res Clin Obstet Gynaecol. 2009;23:519-27.

2. Breen JL. A 21 year survey of 654 ectopic pregnancies. Am J Obstet Gynecol. 1970;106:100419.

3. Celik C, Bala A, Acar A, Gezgine K, Akyurek C. Methotrexate for cervical pregnancy. A case report. J Reprod Med. 2003;48:130-2.

4. Pascual MA, Hereter L, Graupera B. Threedimensional power Doppler ultrasound diagnosis and conservative treatment of ectopic pregnancy in a cesarean section scar. Fertil Steril. 2007;88:706.e5e7.

5. Shinagawa S. Nagayama M. Cervical pregnancy as a possible sequela of induced abortion. Report of 19 cases. Am. J. Obstet. Gynecol. 1969;105:282-284.

6. Rubin IC. Cervical pregnancy.Surg Gynecol Obstet. 1911;13:625-33.

7. Sruddiford WE. Cervical pregnancy: a partial review of the literature and a report of two probable cases. Am. j.Obstet. Gynecol. 1945;49:169-73.

8. Jurkovic D, Hacket E, Campbell S. Diagnosis and treatment of early cervical pregnancy. Ultrasound Obstet Gynecol. 1996;8:373-380.

9. Baptisti A. Cervical pregnancy. Obstet. Gynecol. 1953;1(3):353-8.

10. Burg E. Ueber die zervikale Schwangerschaft. Zentralbl Gynaeko. 1958;80:852-4.

11. Conner E. Cited in Le Cocq F. Discussion of iliac artery ligation in cervical pregnancy. Am J Obstet Gynecol. 1979;134:149.

12. Parente JT, Chau Su Levy J, Legatt E. Cervical pregnancy analysis.A review and report of five cases. Obstet Gynecol. 1983;62:79-82.
13. Ferrara L, Belogolovkin V, Gandhi M, Litton C, Jacobs A, Saltzman D. Successful management of a consecutive cervical pregnancy by sonographically guided transvaginal local injection: case report and review of theliterature. J Ultrasound Med. 2007;26:959-65.

14. Dicker D, Feldberg D, Samuel N, Goldman JA. Etiology of cervical pregnancy: association with abortion, pelvic pathology, IUDs and Asherman's syndrome. J Reprod Med. 1985;30:25-7.

15. Weyerman PC, Verhoeven AT, Alberda AT. Cervical pregnancy after in-vitro fertilization and embryo transfer. Am J Obstet Gynecol. 1989;161:1145-7.

16. Qasim SM, Bohrer MK, Kemmann E. Recurrent cervical pregnancy after assisted reproduction by intra-fallopian transfer.Obstet Gynecol. 1996;87:8312.

17. Bayati J, Garcia JE, Dorsey JH, Padilla SL. Combined intrauterine and cervical pregnancy from in vitro fertilization and embryo transfer. Fertility and Sterility. 1989;51:725-7.

18. Bennett S, Waterstone J, Parsons J. Creighton S. Two cases of cervical pregnancy following in vitro fertilization and embryo transfer to the lower uterine cavity. Journal of Assisted Reproduction and Genetics. 1993;10:100-3.

19. Weyerman PC, Verhoeven AT, Alberda AT. Cervical pregnancy after in vitro fertilization and embryo transfer. Am J Obstet Gynecol. 1989;161:1145-6.

20. Delrieu D, Antaki R, Phillips S, Kadoch IJ. Selective reduction of a triplet heterotopic cervical pregnancy after embryo transfer. Case Reports in Clinical Medicine. 2013;2(9)568-72.

21. Majumdar A, Gupta SM, Chawla D. Successful management of post invitro fertilization cervical heterotropic pregnancy. J Hum Reprod Sci. 2009;2(1):45-6.

22. Ushakov FB, Elchalal U, Aceman PJ, Schenker JG. Cervical pregnancy: Past and future. Obstet Gynecol Surv. 1997;52:45-59.

23. Genc M, Genk B, Kurt S. A Case of Cervical Ectopic Pregnancy:Management and Review of the Literature American Journal of Medical Case Reports. 2014;1:9-15.

24. Marston LM, Dotters DJ, Katz VL. Methotrexate and angiographic embolization for conservative treatment of cervical pregnancy.South Med J. 1996;89:246-8.

25. Sonmez AS, Kafkasli A, Balat O. Cervical pregnancy.Acta Obstet Gynecol Scand. 1994;73:7346.

26. Raskin MM. Diagnosis of cervical pregnancy by ultrasound. A case report. Am J Obstet Gynecol. 1978;130:234-5.

27. Kirk E, Condous G, Haider Z, Syed A, Ojha K, Bourne T. The conservative management of cervical ectopic pregnancies. Ultrasound Obstet Gynecol 2006;27:430-7. 
28. Timor-Tritsch IE, Monteagurdo A, Mandeville EO. Successful management of viable cervical pregnancy by local injection of methotrexate guided by transvaginal ultrasonography.Am J Obstet Gynecol. 1994; 17:737-9.

29. Leeman LM, Wendland CL. Cervical ectopic pregnancy: diagnosis with endovaginal ultrasound examination and successful treatment with methotrexate. Arch Fam Med. 2000;9:72-7.

30. Gun M, Mavrogiorgis M. Cervical ectopic pregnancy: a case report and literature review. Ultrasound Obstet Gynecol. 2002;19:297-301.

31. Vas W, Suresh PL, Tang-Barton PL, Salimi Z, Carlin B. Ultrasonographic differentiation of cervical abortion from cervical pregnancy. J Clin Ultrasound. 1984; 12:553-7.

32. Emerson DS, Cartier MS, Altieri LA, Felker RE, Smith WC, Stovall TG, et al. Diagnostic efficiency of endovaginal color doppler flow imaging in an ectopic pregnancy screening program. Radiology. 1992;183:413-20.

33. Pellerito JS, Taylor KJW, Quedens-Case C, Hammers LW, Scoutt LM, Ramos IM, et al. Ectopic pregnancy: Evaluation with endovaginal color flow imaging. Radiology. 1992;183:407-11.

34. Benson CB, Doubilet PM. Strategies for conservative treatment of cervical ectopic pregnancy. Ultrasound Obstet Gynecol. 1996;8:371-2.

35. Pascual MA, Ruiz J, Tresserra F. Cervical ectopic twin pregnancy: diagnosis and conservative treatment. Human Reproduction. 2001;16(3):584-6.

36. Mashiach S, Admon D, Oelsner G, Paz B, Achiron R, Zalel Y. Cervical Shirodkar cerclage may be the treatment modality of choice for cervical pregnancy. Hum Reprod. 2002;17:493-6.

37. Suzumori N, Katano K, Sato T, Okada J, Nakanishi $\mathrm{T}$, Muto $\mathrm{D}$, et al. Conservative treatment by angiographic artery embolization of an 11-week cervical pregnancy after a period of heavy bleeding. Fertil Steril. 2003;80:617-9.

38. Radpour CJ, Keenan JA. Consecutive cervical pregnancies. Fertil Steril. 2004;81(1):210-3.

39. Cepni I, Ocal P, Erkan S, Erzik B. Conservative treatment of cervical ectopic pregnancy with transvaginal ultrasound-guided aspiration and singledose methotrexate. Fertil Steril. 2004;81:1130-2.

40. Hassiakos D, Bakas P, Creatsas. Cervical pregnancy treated with transvaginal ultrasound-guided intraamniotic instillation of methotrexate. Arch Gynecol Obstet. 2005;271:69-72.

41. Jeng CJ, Ko ML, Shen J. Transvaginal ultrasoundguided treatment of cervical pregnancy. Obstet Gynecol. 2007;109(5):1076-82.

42. Kraemer B, Abele H, Hahn M. Cervical ectopic pregnancy on the portio: conservative case management and clinical review. Fertil Steril. 2008;90(5)2011.e1-e4.

43. Pathak S, Khalil H, Fastovetsv G. Combined Medical - Surgical Management of Cervical Ectopic
Pregnancy - A Case Report. Ultrasound. 2008;16(1):18-20.

44. Verma U, Goharkhay N. Conservative management of cervical ectopic pregnancy Fertil Steril. 2009;91(3):671-4.

45. Song MJ, Moon MH, Kim JA, Kim TJ. Serial transvaginal sonographic findings of cervical ectopic pregnancy treated with high-dose methotrexate. J Ultrasound Med. 2009;28:55-61.

46. Moon HS, Hyun JH, Kim KS, Kim HJ, Moon SE, Koo JS. Use of Tuohy needle for intra amniotic methotrexate injection through the cervical canal in a cervical pregnancy after failure of systemic methotrexate treatment. Am J Obstet Gynecol. 2010;202:e4-e6.

47. Mohebbi MR, Rosenkrans KA, Luebbert EE. Ectopic Pregnancy in the Cervix: A Case Report. Case Reports in Medicine. 2011;858241:2.

48. Shrestha E, Yang Y, Li X, Zhang Y. Successful conservative management with methotrexate and mifepristone of cervical pregnancy. J Biomed Res. 2011;25:71-3.

49. Masuyama H, Inoue S, Nobumoto E. Conservative management of cervical pregnancy: The utility of methotrexate treatment and uterine artery embolization Open Journal of Obstetrics and Gynecology. 2013;3:711-6.

50. Pandey D, Tripathi BN, Pandey S. Cervical ectopic pregnancy presenting as cervical fibroid. J Basic Clin Reprod Sci. 2013;2:132-4.

51. Sijanovic S, Vidosavljevic D, Tapolovec Z. Management of cervical ectopic pregnancy after unsuccessful methotrexate treatment. Iran J Reprod Med. 2014;12(4):285-8.

52. Tomov S, Gortchev G, Tantcev L. Cervical ectopic pregnancy with massive bleeding: a case report. International Journal of Surgery and Medicine. 2015;1(1):22-5.

53. Farabow WS, Fulton JW, Fletcher V, Velat CA, White JT. Cervical pregnancy treated with methotrexate. N C Med J. 1983;44:91-3.

54. American College of Obstetricians and Gynecologists. Medical management of tubal pregnancy. ACOG Practice Bulletin 3. Int J Gynaecol Obstet. 1999;65:97-103.

55. Vela G, Tulandi T. Cervical pregnancy: the importance of early diagnosis and treatment. J Minim Invasive Gynecol. 2007;14:481-4.

56. Hung TH, Shau WY, Hsieh TT, Hsu JJ, Soong YK, Jeng CJ. Prognostic factors for an unsatisfactory primary methotrexate treatment of cervical pregnancy: a quantitative review. Hum Reprod. 1998;12:2636-42.

57. Ben Hamouda S, Ouerdiane N, Daaloul W, Masmoudi A, Bouguerra B, Sfar R. Conservative management of cervical pregnancy. A case-report. Tunis Med. 2008;86:827-9.

58. Api O, Unal O, Api M, Ergin B, Alkan N, Kars B, et al. Ultrasonographic appearance of cervical pregnancy following successful treatment with 
methotrexate. Ultrasound Obstet Gynecol. 2006;28:845-7.

59. Spitzer D, Steiner H, Graf A, Zajc M, Staudach A. Conservative treatment of cervical pregnancy by curettage and local prostaglandin injection. Hum Reprod. 1997;12:860-6.

60. De La Vega GA, Avery C, Nemiroff R, Marchiano D. Treatment of early cervical pregnancy with cerclage, carboprost, curettage, and balloon tamponade. Obstet Gynecol. 2007;109:505-7.

61. Hwang JL, Hsieh BC, Huang LW, Seow KM, Pan HS, Chen HJ. Successful treatment of a cervical pregnancy by intracervical vasopressin. BJOG. 2004;111:387-8.

62. Hsieh BC, Lin YH, Huang LW, Chang JZ, Seow KM, Pan HS. Cervical pregnancy after in vitro fertilization and embryo transfer successfully treated with methotrexate and intracervical injection of vasopressin. Acta Obstet Gynecol Scand. 2004;83:112-4.

63. Kung FT, Chang SY, Tsai YC, Hwang FR, Hsu TY, Soong YK. Subsequent reproduction and obstetric outcome after methotrexate treatment of cervical pregnancy: A review of original literature and international collaborative follow-up. Human Reproduction. 1997;12:591-5.

Cite this article as: Prameela RC, Dev SV. Cervical ectopic pregnancy: 10 year experience at tertiary care hospital and current literature review. Int J Reprod Contracept Obstet Gynecol 2016;5:734-42. 